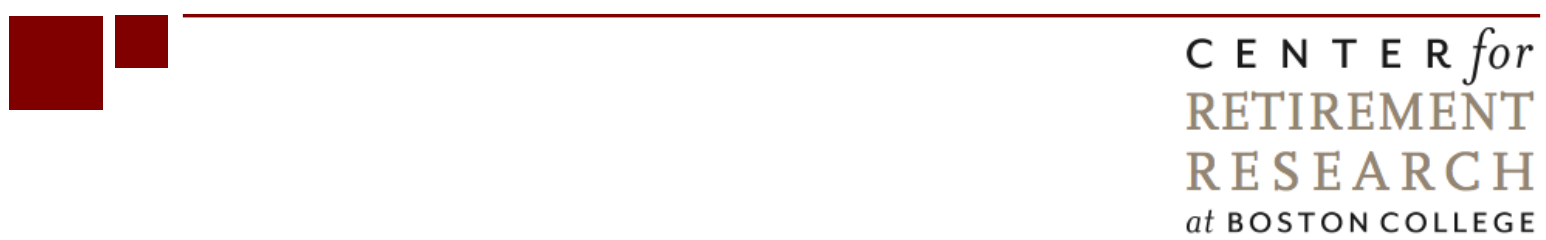

\title{
AN ASSESSMENT OF THE 2001 REFORM OF THE RAILROAD RETIREMENT PROGRAM
}

\author{
Steven A. Sass \\ CRR WP 2013-14 \\ Released: June 2013 \\ Center for Retirement Research at Boston College \\ Hovey House \\ 140 Commonwealth Avenue \\ Chestnut Hill, MA 02467 \\ Tel: 617-552-1762 Fax: 617-552-0191 \\ http://crr.bc.edu
}

Steven A. Sass is the program director of the Financial Security Project at Boston College, an initiative of the Center for Retirement Research. The research reported herein was pursuant to a grant from the Burlington Northern Santa Fe Railway Company, CSX Corporation Inc., Norfolk Southern Corporation, and Union Pacific Corporation. The findings and conclusions expressed are solely those of the author and do not represent the views of the Burlington Northern Santa Fe Railway Company, CSX Corporation Inc., Norfolk Southern Corporation, Union Pacific Corporation, or Boston College.

(C) 2013, Steven A. Sass. All rights reserved. Short sections of text, not to exceed two paragraphs, may be quoted without explicit permission provided that full credit, including (C) notice, is given to the source. 


\begin{abstract}
About the Center for Retirement Research
The Center for Retirement Research at Boston College, part of a consortium that includes parallel centers at the University of Michigan and the National Bureau of Economic Research, was established in 1998 through a grant from the Social Security Administration. The Center's mission is to produce first-class research and forge a strong link between the academic community and decision-makers in the public and private sectors around an issue of critical importance to the nation's future. To achieve this mission, the Center sponsors a wide variety of research projects, transmits new findings to a broad audience, trains new scholars, and broadens access to valuable data sources.
\end{abstract}

\author{
Center for Retirement Research at Boston College \\ Hovey House \\ 140 Commonwealth Avenue \\ Chestnut Hill, MA 02467 \\ phone: 617-552-1762 fax: 617-552-0191 \\ e-mail: crr@bc.edu \\ crr.bc.edu
}

Affiliated Institutions:

The Brookings Institution

Massachusetts Institute of Technology

Syracuse University

The Urban Institute 


\section{INTRODUCTION}

The federal government's Railroad Retirement program is a unique institution. The program is a government program and its assets are government assets. At the same time, Railroad Retirement is the employer pension program of rail workers, who are largely private-sector workers and the program is funded by taxes paid solely by these workers and their employers. The Railroad Retirement and Survivor's Improvement Act of 2001 (RRSIA) introduced four major reforms. It raised benefits, cut taxes, created the National Railroad Retirement Investment Trust (NRRIT) to invest Railroad Retirement assets in equities and other private-sector securities, and it introduced an automatic tax adjustment mechanism to keep the program's finances on-track.

Changes in the Railroad Retirement program are typically initiated by the private-sector parties, in negotiations between rail management and labor. The industry then brings its proposals to Congress for enactment. ${ }^{1}$ The 2001 reform largely enacted the proposals developed by rail management and labor with relatively few changes. Congress's primary concerns, and the major changes it introduced, were in the design of the Investment Trust. This assessment of the reformed Railroad Retirement program and its prospects going forward will thus begin with a review the design of the NRRIT and its governance of Railroad Retirement assets.

\section{THE DESIGN OF THE NATIONAL RAILROAD INVESTMENT TRUST}

Some leading Republican members of Congress and the Bush Administration fiercely opposed the creation of the NRRIT and the investment of "government" assets in equities and other private-sector securities. ${ }^{2}$ The reason was the potential for political influence on investment decisions that would degrade investment performance and - much worse - distort the political process in favor of those who influenced these decisions. The record of state and local pension plans, and the plans of other nations, was full of examples of ssuch influence. ${ }^{3}$

\footnotetext{
${ }^{1}$ Szymendera (2011).

${ }^{2}$ It should be noted that not all Republicans opposed the legislation. Bud Shuster (R-PA) and Don Young (R-AK), two senior House Republicans, supported the bill on pragmatic grounds, believing the reforms would improve the system. Without their support, the bill would not have been passed by the House of Representatives in 2000 or 2001.

${ }^{3}$ See Palacios (2002); Munnell and Sundén (1983); Sass (1992); and Brown, Pollet, and Weisbenner (2009).
} 
What made passions especially intense was the precedent the NRRIT would set for the reform of the nation's Social Security program. Social Security and its funding shortfall were then at the top of the nation's political agenda. The two leading proposals for reform both included investments in equities; but they included equities in very different ways. The Democrats under President Clinton had proposed investing a portion of Social Security's \$2 trillion Trust Fund in stocks. The Republicans under President Bush would allow workers to divert a portion of their Social Security payroll taxes to individual accounts, where the funds could be invested in stocks. The Democrats were confident they could eliminate political influence in the Trust Fund's investment decisions. The Republicans were just as confident they couldn't. And the specter of political influence over the Social Security Trust Fund - 100 times larger than the Railroad Retirement Trust Fund - made the NRRIT and its investment of government assets in equities abhorrent to certain Republicans who were focused on the Social Security policy divide.

While Congress ultimately enacted reform, including the NRRIT, some influential Senators and Representatives were sympathetic to these concerns. Congress's overriding objective in revising the industry plan was thus to eliminate, as much as possible, the potential for political influence on investment decisions. As Railroad Retirement was the employer pension program of the railroad industry, Congress removed government from managing its assets. The industry had proposed a nine-person Board of Trustees, with three Trustees selected by the carriers, three by labor, and three by the Railroad Retirement Board. Congress removed the three Railroad Retirement Board representatives, as the Board was a government agency: the statute specifically stated that "no member of the Railroad Retirement Board shall be eligible to be a member of the Board of Trustees." The organizations representing labor and management, as specified in the Railway Labor Act, would select the six private-sector trustees. Then they, not the government, would select a single "independent" trustee. ${ }^{4}$

\footnotetext{
${ }^{4}$ In 2000, the House of Representatives modified the original labor-management proposal to remove the three members of the Railroad Retirement Board as Trustees, but left the RRB with the responsibility to appoint all seven Trustees. Congressional Record (2001), H7337-38. In 2001, the House of Representatives went further to address continuing concerns about the government retaining any role in the investment activities of the NRRIT, particularly within the Bush Administration, and transferred the power to appoint all seven Trustees from the RRB to the industry. Section 105(j)(3) thus specified that organizations representing and employing, respectively, at least 2/3 of all active workers covered by the Railway Labor Act; Section 105(j)(2).
} 
Congress also moved the NRRIT, and thereby Railroad Retirement assets, out of the government. The statute clearly stated that the entity created to hold and manage Railroad Retirement assets - the National Railroad Investment Trust - "is not a department, agency, or instrumentality of the Government of the United States." The entity was also named a "trust" "to more closely track the structure of private sector pension trusts and "make the investment aspects of the proposal sufficiently 'less governmental.,"5

Private-sector pension trusts themselves had problems with "political influence" on investment decisions - with the plan's company or union sponsors, or executives within those entities, investing pension assets in ways that advanced their interests, not the interests of the plan participants. A major contribution of the Employee Retirement Income Security Act (ERISA) of 1974 was to impose strict new fiduciary standards on the sponsors and managers of private pension plans. Congress now borrowed freely from ERISA to impose similar requirements on the NRRIT. RRSIA required the new Investment Trust to act "solely in the interest of the Railroad Retirement Board and through it, the participants and beneficiaries of the programs funded under this Act." [Italics added] This language specifically forbade any other objective, such as advancing the interests of the carriers or unions - interests ERISA sought to exclude. It also prohibited the advancement of other social or economic goals, as often found in the mandates of other "public" pension programs. ${ }^{6}$

Also borrowing from ERISA, Congress required competent investment management. It couldn't mandate "success." But it did require trustees with "professional" qualifications - with "experience and expertise in the management of financial investments and pension plans"; to invest Railroad Retirement assets with "care, skill, prudence, and diligence" - the ERISA "prudent man" standard; and to diversify asset holdings "so as to minimize risk of large losses" and "avoid disproportionate influence over a particular industry or firm" - a potentially politically problematic influence. ${ }^{7}$

\footnotetext{
${ }^{5}$ Congressional Record (2001) Section 105(a); Salmon (2013) pp. 65, 71; Congress reaffirmed the Trust's status as a non-governmental entity when the Railroad Retirement Board's Inspector General wanted to audit the Trust's operational procedures, considered "best practice" in government audits. In rejecting that request Congress cited its desire that "the Trust functions independently from the U.S. Railroad Retirement Board." U.S. House of Representatives (2007), pp. 9-10.

${ }^{6}$ Sass (1997); Congressional Record (2001) Section 105(a); Mercer (2011); Section 404(a) of ERISA.

${ }^{7}$ Congressional Record (2001) Sections 105(j) 3(B); 105(j)(5)(A)(ii); and 105(j)(5)(A)(iii).
} 
While Congress created the NRRIT as much as it could in the image of a private pension trust, Railroad Retirement remained a government program and its assets government assets. So RRSIA also set up a system of government oversight. The statute required an annual audit by an independent auditor. It also required an annual report, sent to Congress, the President, the Railroad Retirement Board, and the Office of Management and Budget, on the Trust's financial position, cash flows, internal accounting and control systems, and "any other comments and information necessary to inform Congress about the operations and financial condition of the Trust." A Memorandum of Understanding between the Trust and the Railroad Retirement Board, the Treasury, and the Office of Management and Budget would also require monthly reports of gains and losses, sales and purchases, receipts and disbursements, and administrative expenses. If something was amiss, RSSIA authorized the Railroad Retirement Board to go to court "to enjoin any act or practice by the Trust, its Board of Trustees, or its employees or agents that violates any provision of this Act; or "(ii) to obtain other appropriate relief to redress such violations, or to enforce any provisions of this Act." This oversight of the Investment Trust supplemented the existing reports on the financial status of the Railroad Retirement program produced by the Railroad Retirement Actuary - the annual "Section 502" report providing fiveyear projections of the program's finances and the triennial Actuarial Valuations that provided projections over a 75 -year horizon. ${ }^{8}$

\section{THE GOVERNANCE OF RAILROAD RETIREMENT ASSETS}

Congress charged the rail industry to set up and run the NRRIT much like a standard private sector pension trust. And this was something the industry was well equipped to do. Creating the governance structure of a modern pension trust is no simple task. It would take eight months to get the Trust up and running and several more years to fully staff up and define and execute the Trust's investment program. But the roadmap was understood.

RSSIA had set February 1, 2002, as the date the Trust could be created. So between December 21, when President Bush signed RSSIA into law, and February 1 the rail management and labor organizations selected their Trustees. The three carrier Trustees were Thomas N. Hund, James A. Hixon, and Bernie Gutschewski; the three from labor were Joel Parker, Daniel

\footnotetext{
${ }^{8}$ Congressional Record (2001) Section 105(j)(5)(E); Section 105(j)(5)(F); Section 108(b). The Memorandum of Understanding also outlined procedures for transferring assets between the Treasury and the Trust.
} 
E. Johnson, III and George J. Francisco, Jr. ${ }^{9}$ When they met on February 1, the six Trustees adopted a set of bylaws, secured the necessary insurances and bonding, selected Parker as chair, set up Investment, Administration, and Audit Committees, and selected Dewey Ballantine LLP (outside counsel to the Union Pacific) and Guerrieri, Edmond, and Clayman PC (a firm close to labor) as Trust co-counsels. Hixon, Gutschewski, Parker, and John Salmon, of Dewey Ballantine, were leading players in the negotiations creating the industry reform proposal and in the lobbying effort to win Congressional passage.

The Trustees then went to work to create a modern "institutional" investment organization. They met with senior investment managers in major corporate and multi-employer pension trusts for guidance and advice. They conducted nationwide searches that resulted in the selection of John W. MacMurray, a seasoned pension executive as the NRRIT's "independent" trustee in May; of Northern Trust as Trust Custodian in July; and of Enos T. Throop as Chief Investment Officer in August. ${ }^{10}$ Following directives in the statute, they developed a compensation package with "terms and conditions as are customary" in the investment management industry for Throop and other Trust employees. Congress explicitly included this requirement as the terms and conditions of employment were quite different from those offered public sector workers, and needed to be offered to attract and retain effective investment managers. Also following RSSIA, the Trustees retained "independent advisers to assist it in the formulation and adoption of its investment guidelines," commissioning an asset-liability study from Watson Wyatt that was finalized in August. They then retained "independent investment managers to invest the assets of the Trust in a manner consistent with such investment guidelines, selecting Barclays Global Investors in September as the Trust's first investment manager. Barclays managed passive stock and bond index funds, which is where the Trustees placed their first investments. As the Trust staffed up and developed greater managerial capacity, it would move the bulk of its assets to active external investment managers. But the

\footnotetext{
${ }^{9}$ Thomas N. Hund was Executive Vice President and Chief Financial Officer of the Burlington Northern-Santa Fe; James A. Hixon was Senior Vice President-Administration of the Norfolk Southern, and Bernie Gutschewski was Vice President - Taxes, for the Union Pacific. Joel Parker was International Vice President, Transportation Communications Union, Daniel E. Johnson, III was Secretary-Treasurer of the United Transportation Union, and George J. Francisco, Jr. was President of the National Conference of Firemen and Oilers.

${ }^{10}$ When hired, Throop was the Director of Investments of the UMWA Funds, and had more than 25 years of investment management experience working for plan sponsors.
} 
Trust was now ready - eight months after its creation - to manage the assets of the Railroad Retirement program. ${ }^{11}$

Consistent with the intent of Congress, the Trustees created added safeguards against "political" influences on investment decisions. ERISA allowed pension trusts to invest up to10 percent of their assets in the sponsor's securities. As the language in RSSIA seemed to frown on such investments, the Trustees agreed not to invest any Railroad Retirement assets in securities issued by North American railroads. The pension fund would not be seen as a "captive source of credit" for the industry, or any firm in the industry. The Trustees also decided to restrict active investment managers to oversee no more than 10 percent of Trust Fund assets. While the primary purpose was to promote diversification, the policy would also limit any perceived influence on the broader U.S. economy. Finally, the Trustees adopted institutional investor "best practice" for voting proxies. It delegated proxy voting to the Trust's external investment managers with the mandate that "all proxies shall be voted solely in the interest of plan participants and beneficiaries."12

The "politics" of the Board was also conducive to effective Trust Fund management. Various Trustees report a high degree of comity, with essentially no disagreements between management and labor, and the Trustees making decisions in an efficient, business-like manner. A contributing factor could be joint management-labor effort in winning Congressional approval of the 2001 reform. Another could be the distribution of risk. The carriers bore all the downside risk. The tax adjustment mechanism RSSIA introduced would raise the carriers' payroll tax, not the workers' payroll tax, if the finances of the program weakened beyond specified benchmarks. As the carriers were also far more willing and able than labor to bear that downside risk, this removed a potential area of conflict between management and labor Trustees. Whatever the reason, the Board, by all reports, was generally united reaching its investment and managerial decisions.

\footnotetext{
${ }^{11}$ Congressional Record (2001) Section 105(j)(4); Section 105(j)(6); National Railroad Retirement Investment Trust (2002).

${ }^{12}$ The Trustees drew up a list of 10 North American railroad companies, later expanded, whose securities the Trust would not purchase. Their securities could only be held indirectly within of a passive Index fund. Also cite the Trust's Proxy Voting Statement; explanation in writing.
} 


\section{PERFORMANCE OF THE TRUST TO DATE}

The Trust began receiving Railroad Retirement assets in September 2002, once its basic investment infrastructure was in place. By the end of March 2003, the transfer was largely complete. As it turned out, this was a remarkably fortuitous time for the Railroad Retirement program to sell bonds and buy stock. ${ }^{13}$

The shift in Railroad Retirement investments from government bonds to private-sector securities came just after the 2001 recession had ended. The market interest rate on intermediate-term Treasuries, which the Railroad Retirement program held, had fallen precipitously (Figure 2.1). The program's bonds thus had an above-market yield, and produced a substantial capital gain when sold. The funds were transferred to the NRRIT $-\$ 21.3$ billion by the end of the first quarter of 2003. The funds were invested in Barclay stock and bond index funds and by the end of the 2003 fiscal year had annualized returns of nearly 20 percent. ${ }^{14}$

RRSIA had established the "account benefit ratio" - the ratio of the market value of Railroad Retirement assets to annual benefit outlays - as the basic yardstick for measuring the financial health of the program. Despite the sweetened benefits and lower taxes reform introduced, the capital gains on the sale of Trust Fund bonds and the returns achieved on Trust Fund investments pushed the Railroad Retirement account benefits ratio from 6.2 to 6.6 times annual benefits over the course of the 2003 fiscal year. ${ }^{15}$

\footnotetext{
${ }^{13}$ National Railroad Retirement Investment Trust (2006).

${ }^{14}$ National Railroad Retirement Investment Trust (2002).

${ }^{15}$ National Railroad Retirement Investment Trust (2003).
} 
Figure 2.1. Market Interest Rate, Intermediate-Term Government Bonds

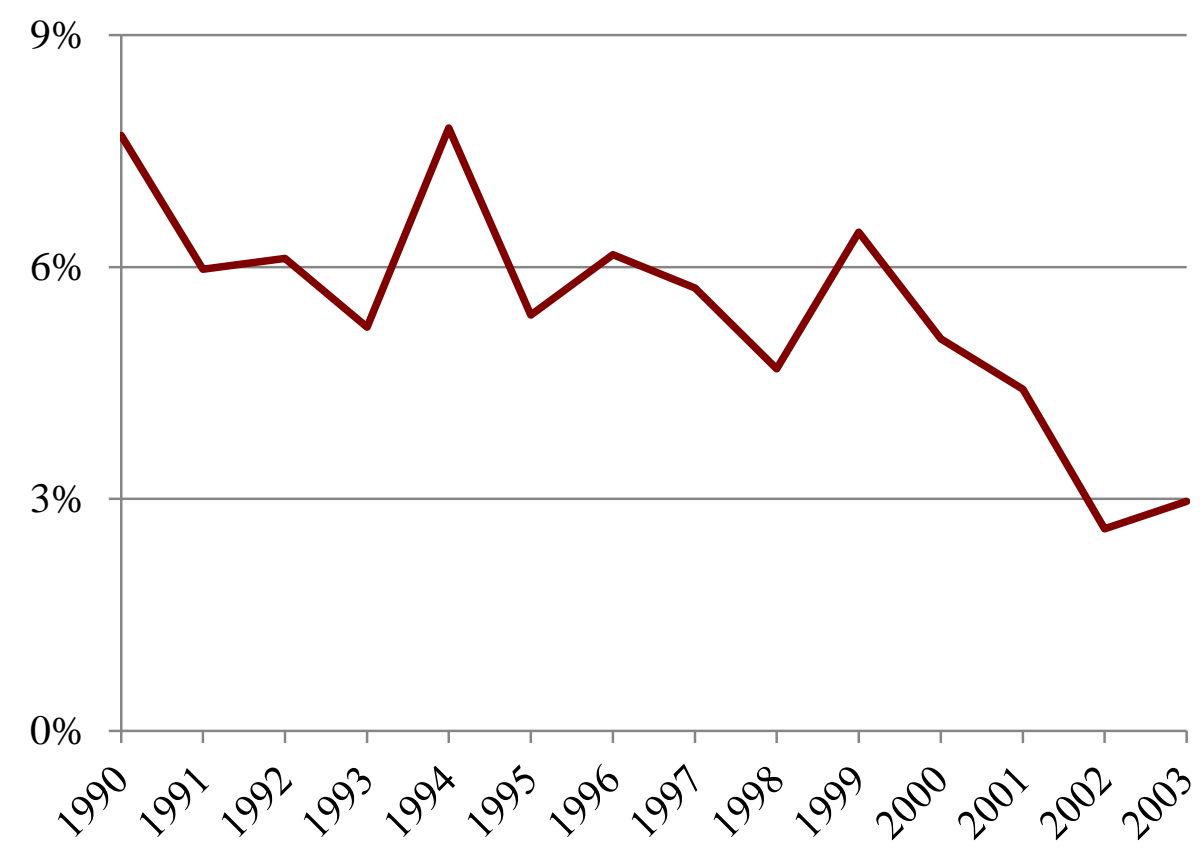

Source: Ibbotson Associates (2013).

The interest rate decline that produced the capital gain on Railroad Retirement bonds and boosted the program's account benefits ratio - the yardstick used to measure the health of the program - had a very different effect on the "funded ratio" of private defined benefit pension plans - the yardstick used to measure the health of such plans. The funded ratio is the ratio of trust fund assets to the present value of plan obligations. It reports whether the plan has sufficient assets in-hand to meet those obligations. The obligations of a pension plan stretch far into the future and by statute must be valued using current interest rates on high quality corporate bonds. Just as the decline in interest rates raised the value of Treasuries held by the Railroad Retirement system, it raised the present value of private pension obligations. The interest rate decline was in fact the main contributor to the dramatic fall in the funded ratios of private plans in the early 2000s. Congress, concerned that plan sponsors and their plans could go bust and transfer large unfunded obligations to the government's Pension Benefit Guarantee Corporation, had over time required sponsors to rapidly eliminate shortfalls when the shortfalls grew beyond specified levels. These rules resulted in contributions tripling in the recession at the turn of the 
century and were a major factor in sponsor decisions to terminate, freeze, or otherwise abandon their defined-benefit pension programs. ${ }^{16}$

Government-run social insurance programs do not have the same bankruptcy risks as private defined benefit plans. Thus the funded ratio, which uses the present value of plan obligations as the yardstick for assessing the adequacy of pension plan assets, is far less useful for assessing the health of such programs. Railroad Retirement, however anomalous, is a government-run social insurance program. It might be argued that the interest rate decline should trigger a reduction in the expected return on Trust Fund assets, which could require an offsetting increase in Railroad Retirement payroll taxes. But no such relationship was present in RSSIA's tax adjustment "ratchet," which based payroll taxes solely on the ratio of assets to annual benefit payments.

Whatever the implications of the decline in interest rates on expected returns, the returns on stocks the Trust bought in 2002- 2003 were remarkably good. The promise of higher returns on equities had been the primary factor driving management and labor to reform the Railroad Retirement program. And the gains from investing in stocks - up until the Crash of 2008 exceeded all expectations (Figure 2.2).

Figure 2.2. Real Returns on Large Company Stocks. Index, $2002=100$

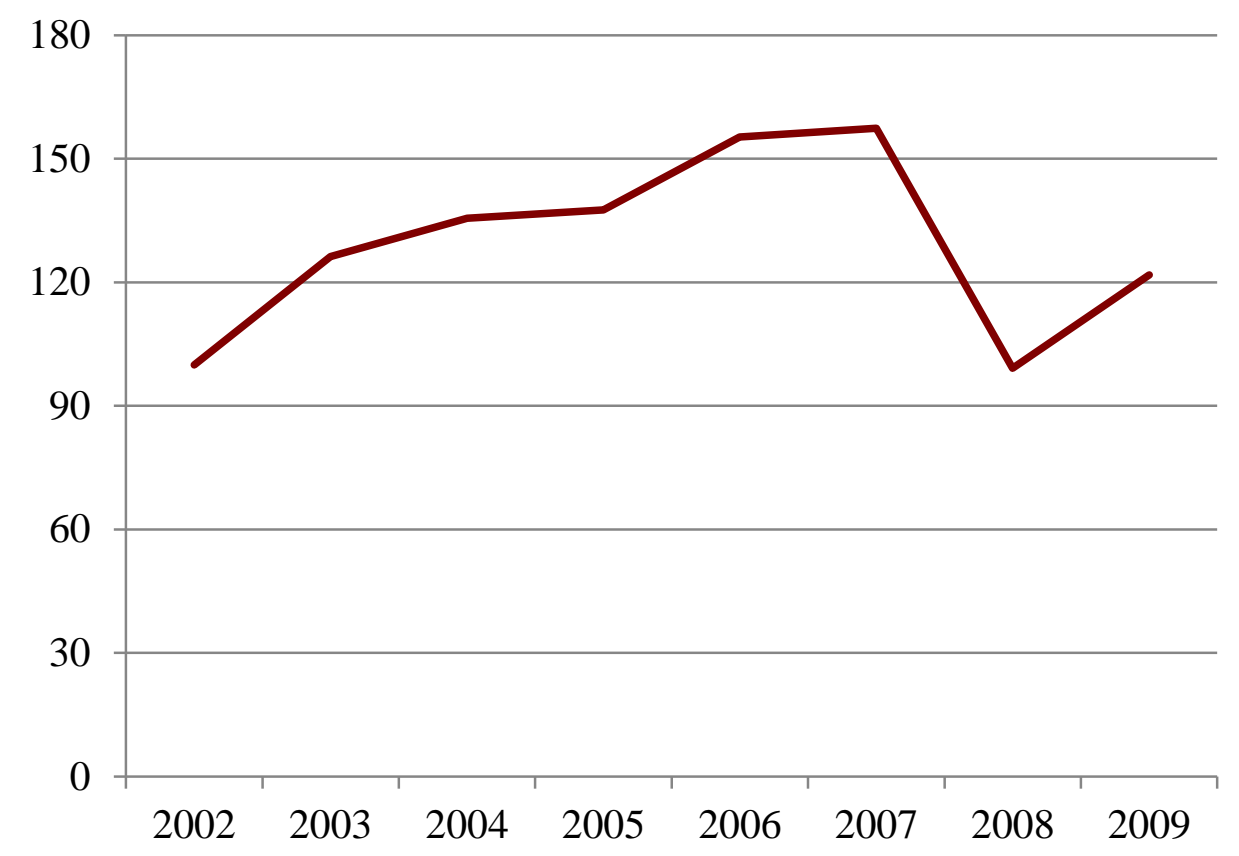

Source: Ibbotson Associates (2003).

\footnotetext{
${ }^{16}$ Munnell and Sass (2006).
} 
Determining the share of Trust Fund assets to invest in stocks, and which type of stocks; how much to invest in bonds, and which type of bonds; and how much to invest in other types of assets, such as real estate and private equity, is a difficult issue. The fundamental objective of any pension trust is to provide the cash the plan needs, when it needs it, to pay promised benefits. The "gain" the 2001 reform divided between management and labor - like the "gain" management and labor divide in private pension plans - involved investments in equities and taking on risk. So the Trustees, "in accordance with statutory directives," defined as its two "principle objectives: (i) to ensure the timely and certain payments of benefits to eligible railroad retirement plan participants and beneficiaries, and (ii) to achieve a long term rate-of-return on assets sufficient to enhance the financial strength of the Railroad Retirement System." The prudence and diversification RSSIA required could enhance the certainty of benefit payments and reduce other financial risks - but only so far without also reducing expected returns. So setting the Trust's "Investment Guidelines" - its mix of assets and how much and what type of risks to take on - was the fundamental decision the Trustees had to make. ${ }^{17}$

RSSIA clearly stated that the Trustees "shall ... retain independent advisers to assist it in the formulation and adoption of its investment guidelines," which had to be approved by "a unanimous vote of the entire Board of Trustees." 18 The Board retained Watson Wyatt to produce an asset-liability study that recommended the following strategy, which the Trustees unanimously adopted:

Table 2.1. NRRIT Initial Investment Guidelines

A. Target Asset Allocation Strategy

\begin{tabular}{lcc}
\hline Asset class & Policy target & Target range \\
\hline Equity & $65 \%$ & $60-70 \%$ \\
Domestic (U.S.) equities & 40 & $34-46$ \\
International equities & 20 & $17-23$ \\
Private equities & 5 & $3-7$ \\
\hline Fixed income (including cash) & 35 & $30-40$ \\
Investment grade bonds & 30 & $25-35$ \\
High yield bonds & 5 & $3-7$ \\
\hline
\end{tabular}

Source: National Railroad Retirement Investment Trust (2003).

\footnotetext{
${ }^{17}$ National Railroad Retirement Investment Trust (2002).

${ }^{18}$ Congressional Record (2001) Section 105(j)(4)(A); Section 105(j)(7).
} 
The guidelines gave the Trustees some flexibility to alter asset allocations in response to market conditions. But they limited the range of deviation. As changes in the price of stocks and bonds shift the value of assets invested in each class, the Trust rebalances on a quarterly basis: It sells assets above their target allocation to provide any additional cash the plan needed to pay benefits, or to buy assets below their allocation target.

The Watson Wyatt guidelines were relatively aggressive. High yield bonds have relatively high expected returns and risk - a financial profile much like equities. So the guidelines allocated 70 percent of Trust Fund assets to investments with high expected returns and risk and 30 percent to investment grade bonds, securities with relatively low expected returns and risk. International and private equity and high-yield bonds have different risks than domestic equities, the primary risk-asset held by the Trust. So the allocation dampened the expected volatility of Trust Fund returns. The Trustees would add new asset classes, such as overseas bonds, real estate, commodities, "opportunistic" hedge funds, and cash; and also set allocations and performance benchmarks for finer classifications within these asset classes.

As shown in Figure 2.3, the NRRIT achieved returns that "generally compared favorably" to its benchmarks - indexes used to evaluate the performance of investment managers. But as the Figure shows, the Trust's "strategic" investment allocation and the performance of the financial markets has been far more important that its own "tactical" performance vis-à-vis its benchmarks. The Trust's investment strategy produced returns well above expectations through fiscal 2007. But returns over the next four years, through the Crash of 2008 and Great Recession that followed, were far worse than anyone could have expected. 
Figure 2.2. NRRIT Returns vis-à-vis Policy Benchmark.

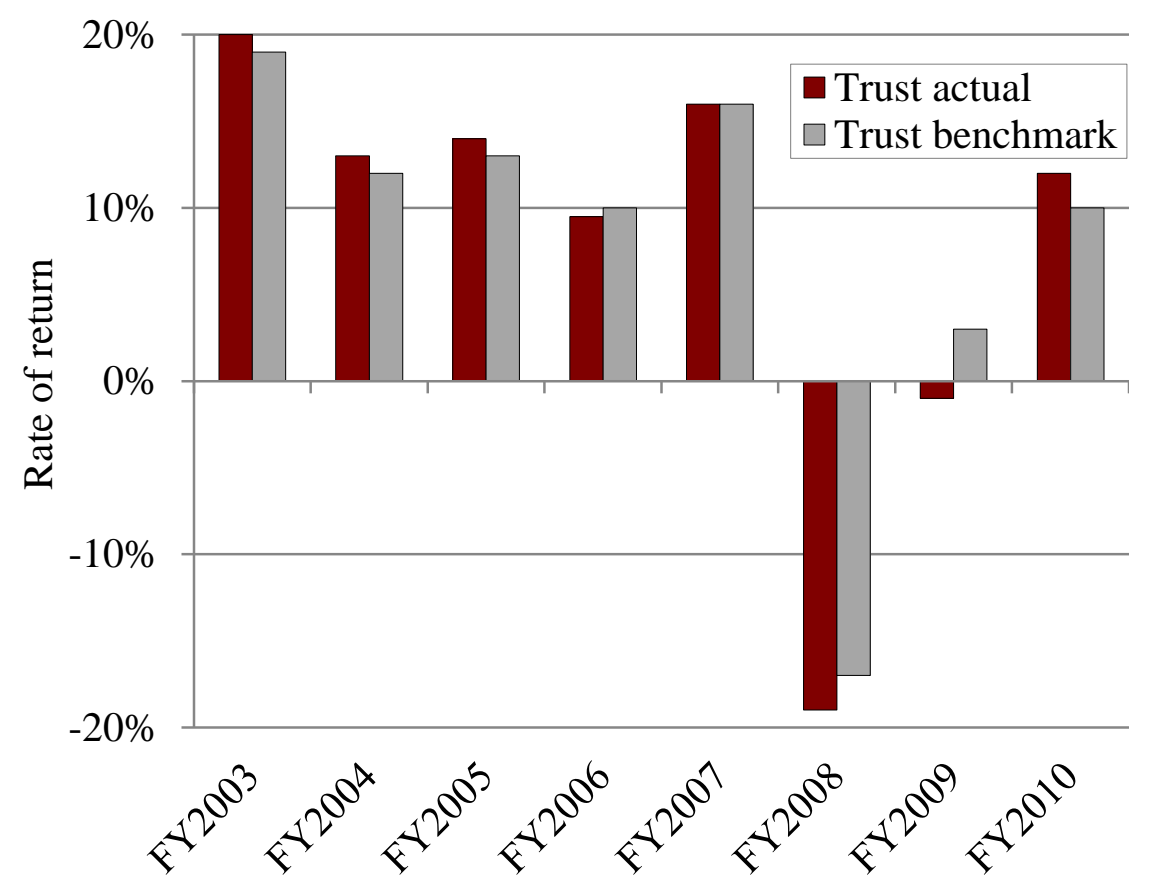

Source: Szymendera (2011) using data from National Railroad Retirement Investment Trust (Various years).

The Crash also sparked a scramble for liquidity as the financial markets froze up. The Railroad program was quite dependent on transfers from the NRRIT to pay benefits. The 2001 benefit increases and tax cuts, and further cuts produced by the tax adjustment ratchet in response to the dramatic rise in Trust Fund assets and the program's account benefits ratio, had created a substantial gap between annual benefit outlays and incoming tax receipts. The payroll tax and income taxes on benefits, which were returned to the Railroad Retirement program, covered just 70 percent of outlays in 2008. Transfers from the NRRIT were needed to cover the remaining 30 percent. The experience of the 2008 financial crisis and the Railroad Retirement program's dependence on transfers from the Trust led the NRRIT to i) bulk up in cash until the markets returned to more normal conditions and ii) eliminate securities lending, which trimmed returns by a negligible few basis points. But investment policy was otherwise little changed. The 2011 guidelines of major asset classes, with the performance benchmarks for each, are 
presented in Table 2.2. The allocation remained relatively aggressive, with the added diversification somewhat dampening the expected volatility of Trust Fund returns. ${ }^{19}$

Table 2.2. NRRIT 2011 Investment Guidelines

\begin{tabular}{|c|c|c|c|}
\hline Asset class & Policy benchmark & Target allocation & Policy range \\
\hline U.S. equity & Russell 3000 & $23 \%$ & $18-28 \%$ \\
\hline Non-U.S. equity & MSCI ACWI Ex-U.S. IMI-\$Net & 21 & $16-26$ \\
\hline Private equity & $\begin{array}{l}\text { 2/3 Russell } 3000+1 / 3 \mathrm{MSCI} \\
\text { ACWI Ex U.S. IMI-\$Net }+300 \mathrm{bp}\end{array}$ & 10 & $2-15$ \\
\hline Global equity & & 54 & $45-61$ \\
\hline U.S. fixed income & Barclays U.S. Universal & 13.5 & $9-18$ \\
\hline Non-U.S. fixed income & Barclays Global Aggregate ex-USD & 8.5 & $5-15$ \\
\hline Global fixed income & & 22 & $18-28$ \\
\hline Real estate & $\begin{array}{l}\text { 80\% NCREIF Property Index + } \\
20 \% \text { Custom REIT }\end{array}$ & 10 & $2-15$ \\
\hline Commodities & DJ-UBS Total Return & 5 & $2-8$ \\
\hline Global real estate & & 15 & $10-20$ \\
\hline Absolute return & NRRIT Public Markets Composite & 8 & $2-10$ \\
\hline Cash & BofA ML 3-Month T-bill & 1 & $0-3$ \\
\hline Other & & 9 & $2-12$ \\
\hline Total fund & & 100 & \\
\hline
\end{tabular}

${ }^{1}$ NRRIT's Custom REIT benchmark is 2/3 "FTSE NAREIT Equity REIT index" and 1/3 "FTSE EPRA/NAREIT Global Real Estate Index - Net Return to U.S. Investors

Source: Appendix to the National Railroad Retirement Investment Trust (2011).

Investment returns through the end of fiscal 2011, though below expectations at the beginning of the decade, were nonetheless sufficient to help produce an account benefit ratio of 4.75 times annual outlays for 2012, somewhat above the 4.62 ratio for 2012 projected at the beginning of reform. ${ }^{20}$ By this measure, the creation of the NRRIT has thus far proved a success.

\section{THE PERFORMANCE OF THE REFORMED SYSTEM TO DATE}

The 2001 reform of the Railroad Retirement program had four elements. It raised benefits, cut taxes, created the NRRIT, and introduced the tax adjustment ratchet to keep the program's finances on-track. The tax cuts, benefit increases, and early retirements financed by the benefit

\footnotetext{
${ }^{19}$ National Railroad Retirement Investment Trust (2008) characterized the allocation as "a structure which is more fully diversified across geography, capitalization size, style, credit quality and many other characteristics" (p1.6) and "addresses asset allocation across a spectrum of active risk levels and degrees of liquidity" (p.17).

${ }^{20}$ U.S. Railroad Retirement Board (2003 and 2012), using employment projection I.
} 
increases (which reduced payroll tax revenues), weakened the system's finances. These effects were expected. The Congressional Budget Office estimated the cost of these changes at $\$ 7$ billion over the first 10 years following the enactment of reform. The higher expected returns on Trust Fund assets and the tax adjustment ratchet were designed to see that Railroad Retirement benefits were nonetheless paid (Figure 2.4).

Figure 2.4. Projected Tax Income and Benefit Outlays, Pre and Post Reform

A. Pre reform

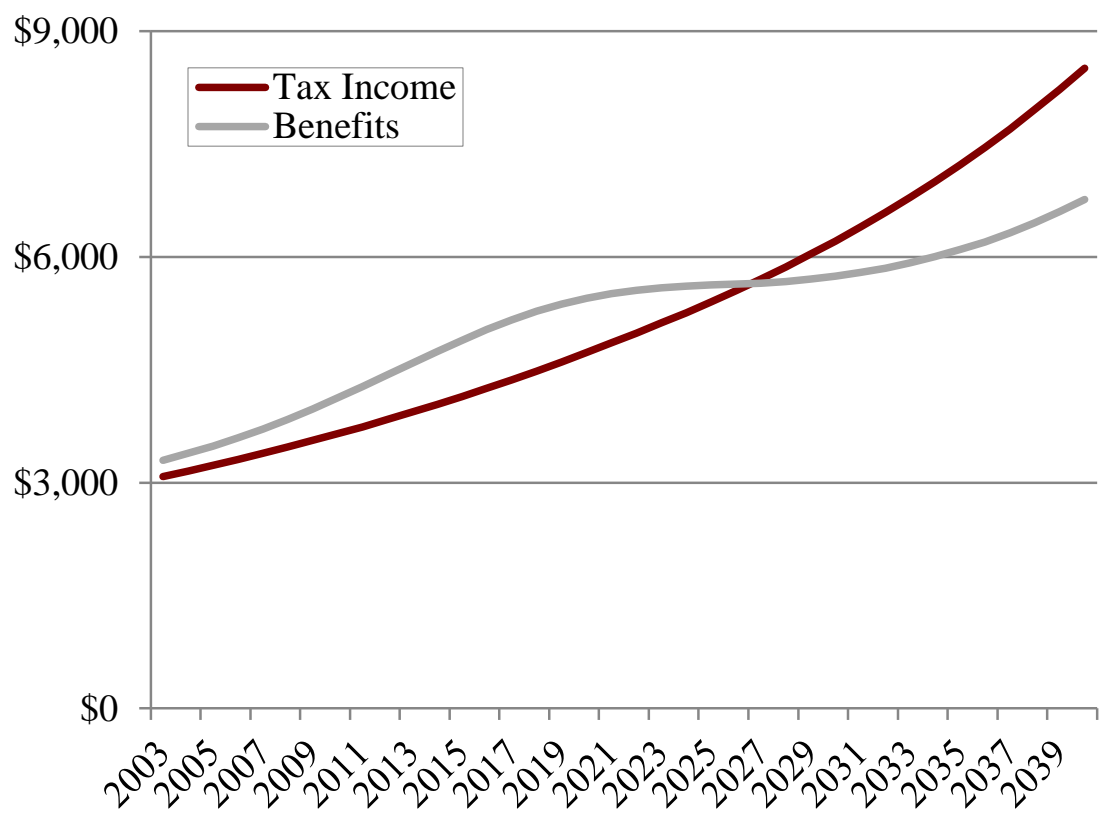


B. Post reform

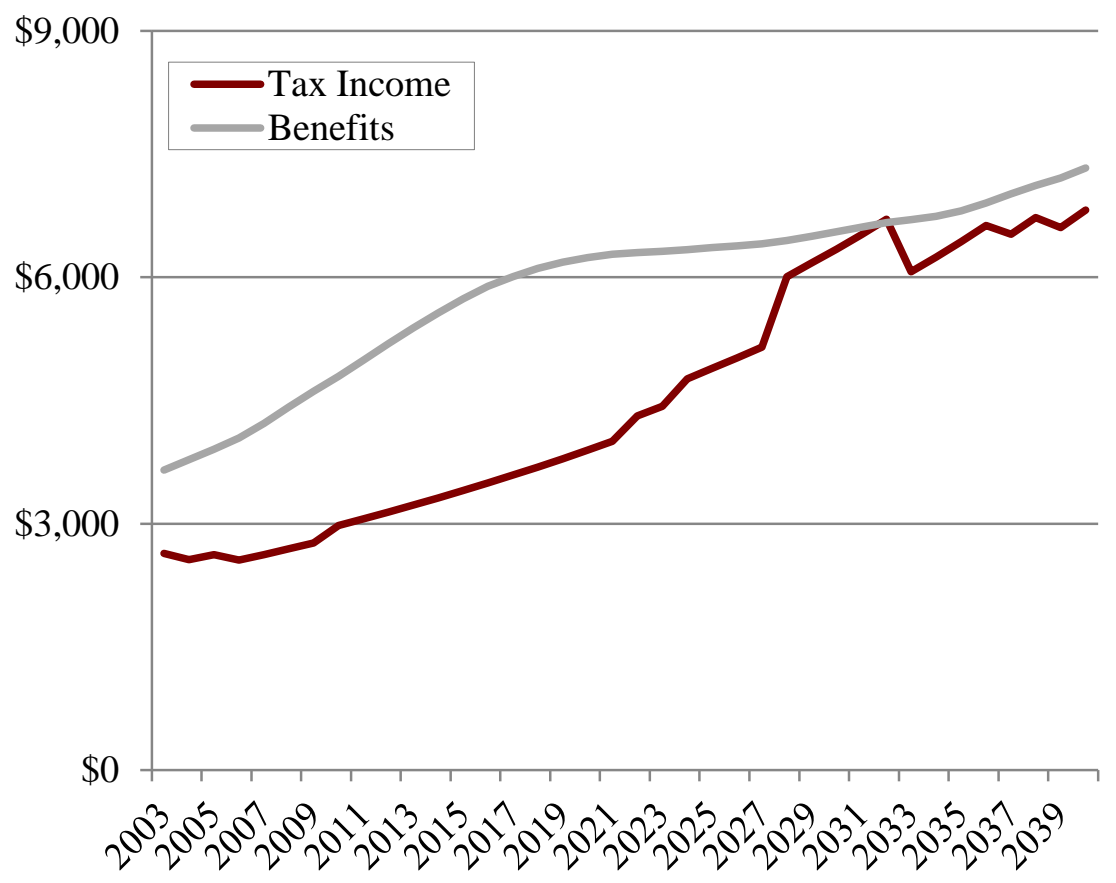

Source: U.S. Railroad Retirement Board (2000 and 2003), using employment projection I.

As discussed above, returns on Trust Fund assets exceeded expectations through 2007. The tax adjustment ratchet set the payroll tax on workers and carriers based on a 10-year trailing average of the ratio of assets to outlays (Figure 2.5). The strong investment returns through 2007 pushed the10-year average "account benefit ratio" to just below 7 times annual benefit outlays, triggering two separate tax reductions in the payroll tax, reducing the total tax to 16 percent of covered earnings -12.1 percent paid by the carriers and 3.9 percent paid by workers (Figure 2.6). 
Figure 2.5. The Tax Adjustment Ratchet

Railroad Retirement Payroll Tax Based on 10-Year Average Ratio of Assets to Annual Outlays

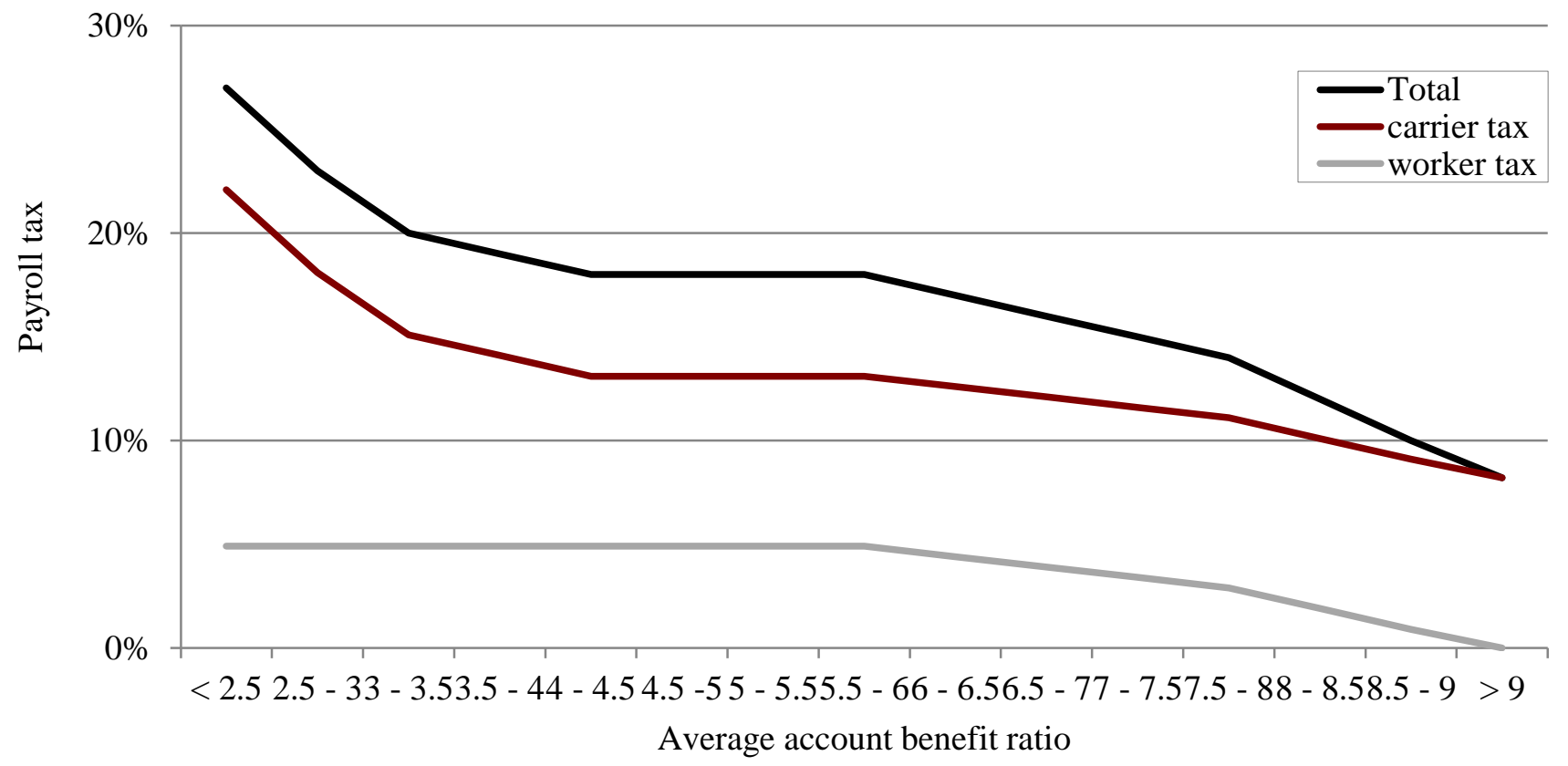

Source: Congressional Record (2001).

Figure 2.6. Average Account Benefit Ratios and Payroll Tax Rates, 2004-2012

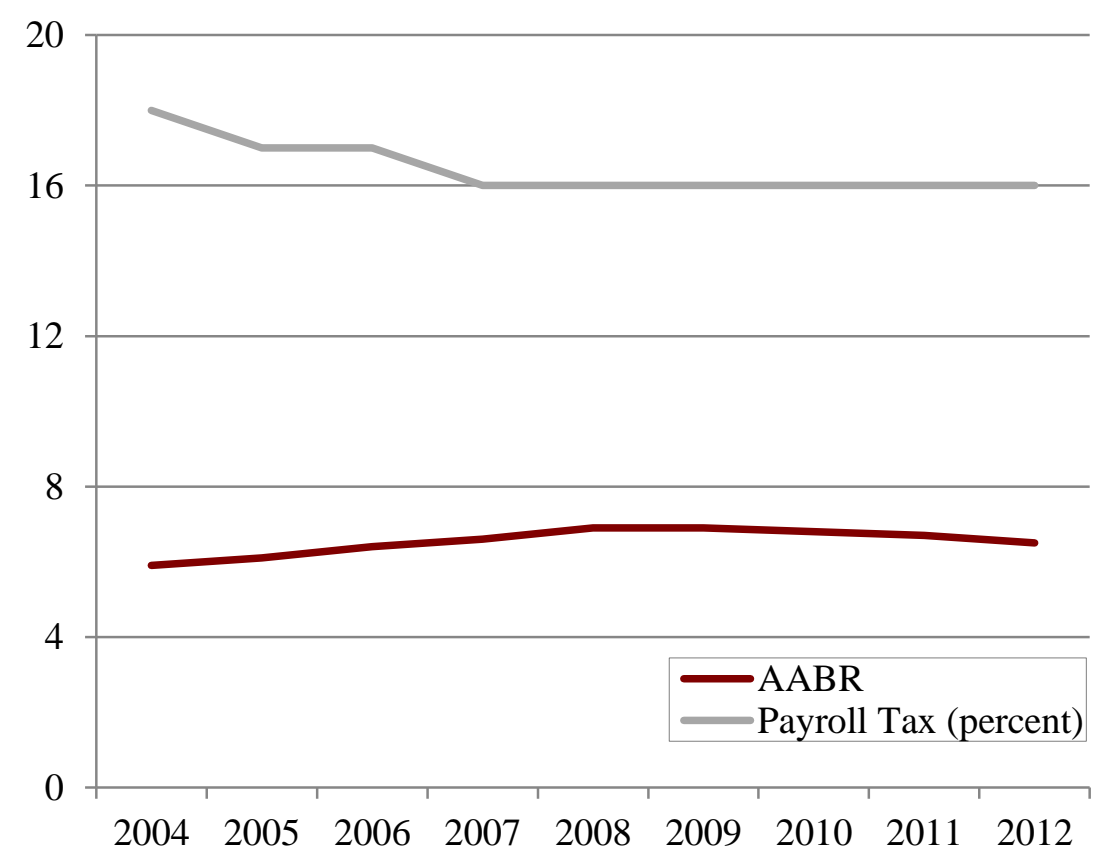

Source: National Railroad Retirement Investment Trust (Various years). 
The unexpected tax reductions arrived as the "watermelon entered the snake" - as the gap between benefit outlays and tax receipts widened and had to be filled with larger transfers from the NRRIT. The system needed $\$ 1.3$ billion from the Trust to pay promised benefits in fiscal 2008 - 30 percent of that year's benefit outlays. This was four percent of Trust Fund assets of $\$ 32.7$ billion at the beginning of the year. But then the market crashed. The value of Trust Fund assets fell 19 percent in fiscal 2008. After transferring the $\$ 1.3$ billion, the value of assets in the Trust assets fell 23 percent, from $\$ 32.7$ to $\$ 25.3$ billion. By the end of fiscal 2008 , and the ratio of assets to outlays fell from 7.9 to 6.1 times annual outlays (Figure 2.7).

Figure 2.7. Trust Fund Assets and Account Benefit Ratios, 2004 -2011

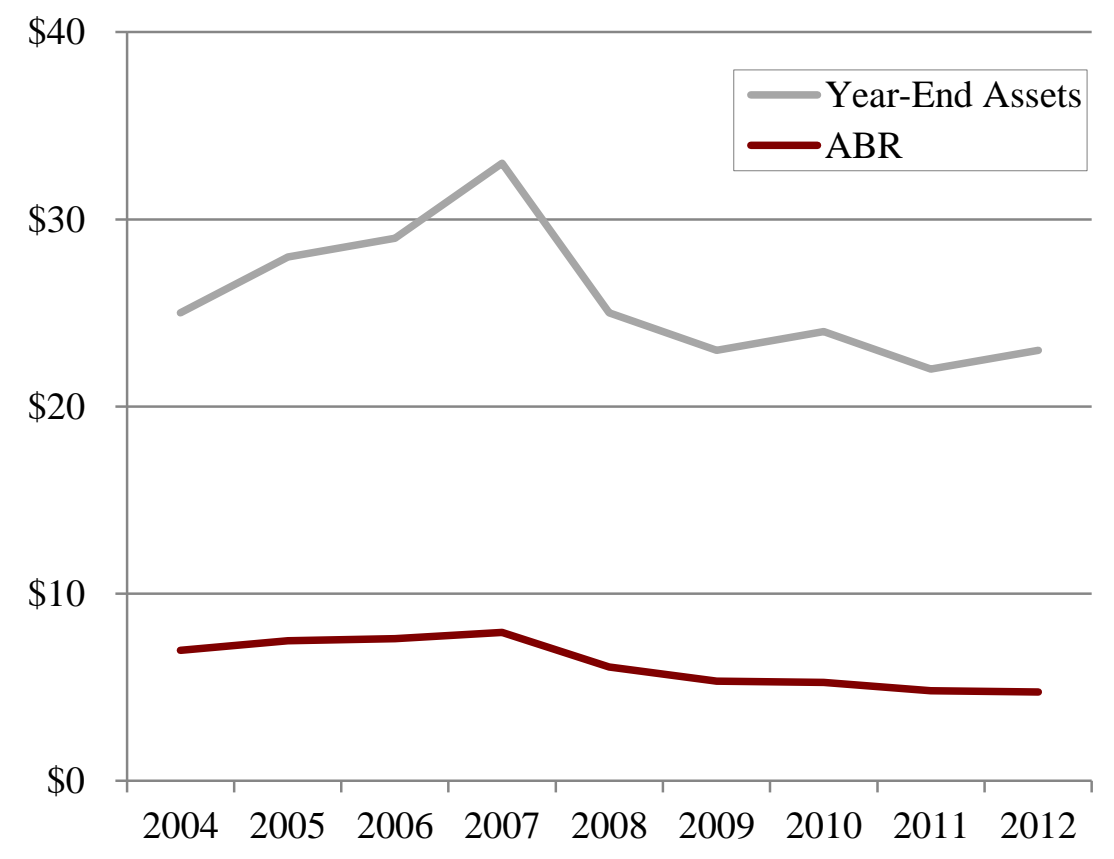

Source: National Railroad Retirement Investment Trust (Various years) and U.S. Railroad Retirement Board (2012).

Investment returns were also disappointing in fiscal 2009 and 2011, the program took more than the Trust Fund earned to pay benefits, and the program's account benefits ratio fell to 4.75 percent of benefits by 2012 (Table 2.3 ). 
Table 2.3. NRRIT Investment Returns, Transfers to Pay Benefits, and Account Benefits Ratio $(A B R)$

\begin{tabular}{lcccc}
\hline & \multirow{2}{*}{ Investment returns } & \multicolumn{3}{c}{ Transfers } \\
\cline { 3 - 4 } & & As \% of benefits & As \% of initial assets & ABR \\
\hline 2004 & $13.0 \%$ & $45 \%$ & $7.0 \%$ & 6.98 \\
2005 & 14.0 & 22 & 3.2 & 7.49 \\
2006 & 9.8 & 23 & 3.2 & 7.61 \\
2007 & 16.4 & 34 & 4.8 & 7.94 \\
2008 & -19.1 & 31 & 4.0 & 6.09 \\
2009 & -0.7 & 37 & 6.3 & 5.33 \\
2010 & 11.2 & 44 & 8.6 & 5.27 \\
2011 & -0.1 & 37 & 7.1 & 4.81 \\
2012 & 16.4 & 39 & 8.6 & 4.75 \\
\hline
\end{tabular}

Source: National Railroad Retirement Investment Trust (Various years) and U.S. Railroad Retirement Board (2012).

Despite this clear decline in the system's finances since the Crash of 2008, payroll tax rates remained unchanged at 16 percent of covered earnings through 2012. The tax adjustment ratchet adjusts tax rates based on the average account benefit ratio over the preceding 10 years. $^{21}$ As shown in Figure 2.7, that average trended down slowly and only crossed the 6.5 threshold at the end of fiscal year 2012, triggering a 6 percent increase in the payroll tax to 17 percent of covered earnings in calendar year 2013. The tax will likely rise another 6 percent, to $18 \%$ of covered earnings, in calendar year 2015. Only then, seven years after the Crash of 2008, will the payroll tax return to its benchmark 18 percent rate, for average account benefit ratios within the target band of 4 to 6 times annual benefit outlays.

What strengthened the system during this difficult investment period was the unexpected stability of railroad employment. Rail employment had declined dramatically over the entire post-World War II era, and falling employment is the worst of all possible environments for payas-you-go retirement programs. Under all employment projections, rail employment was projected to continue to fall in the future and the debate in projecting the finances of the program was how steep the fall would be. Despite the significantly enhanced incentive to retire early that the 2001 the reform introduced, which could retire workers that the carriers deemed expendable but would be difficult to dismiss, rail employment remained remarkably strong. By 2010, rail employment was even greater than the optimistic projection of the pre-reform actuarial

\footnotetext{
${ }^{21}$ Rounded UP to the nearest tenth.
} 
valuations (Figure 2.8). This stronger than expected employment performance produced unexpectedly strong payroll tax receipts. This helped offset the lackluster performance of the financial markets after the 2008 crash and the delayed response of the ratchet to the program's falling ratio of assets to outlays.

Figure 2.8. Actual Railroad Employment Compared to Various Assumptions of 21st Actuarial Valuation

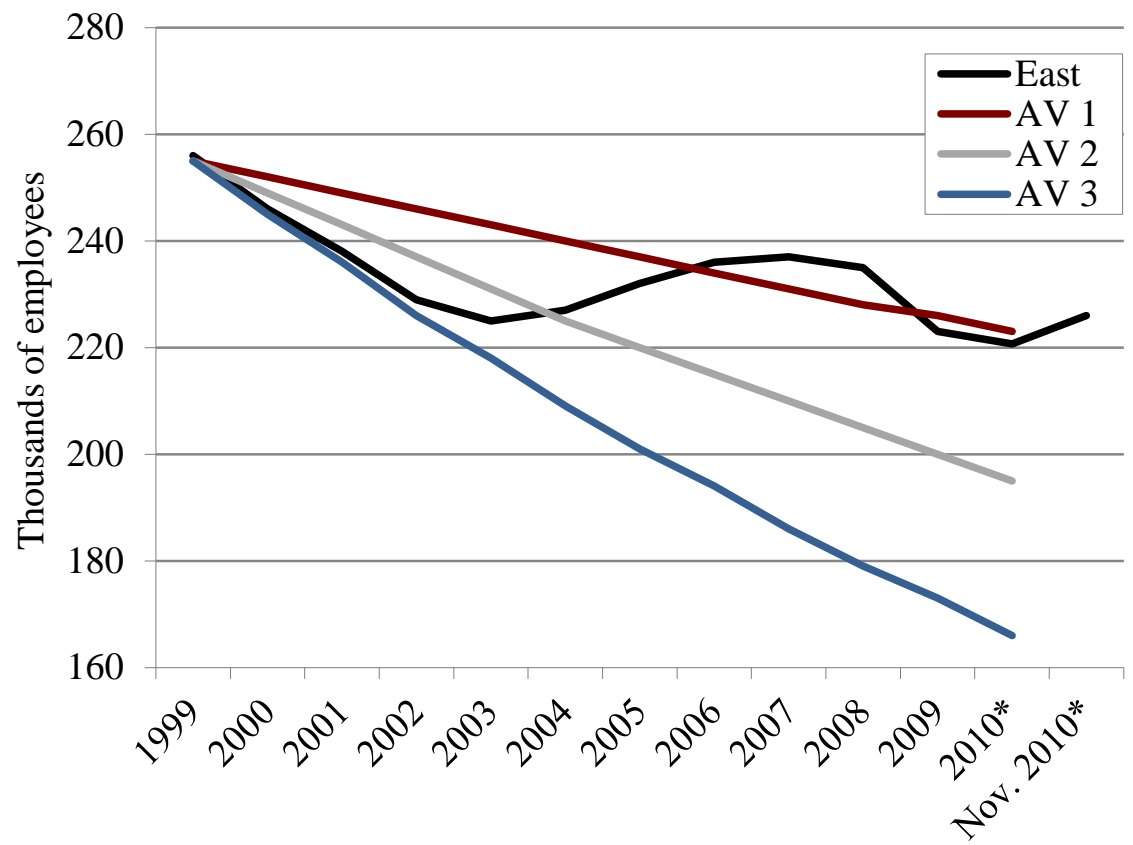

*Actual employment figure represents average from January-November of 2010.

Source: Salmon (2013).

\section{PROSPECTS GOING FORWARD}

The success of the 2001 reform critically depends on how well the program negotiates the "watermelon in the snake" - the wide gap between outlays and tax receipts projected over the next ten to fifteen years. The key variable in the most recent Actuarial Valuation, released in June 2012, is the path of future railroad employment (Figure 2.9). ${ }^{22}$ The most optimistic projection, Assumption I, based on a mild decline in railroad employment, has the account

\footnotetext{
${ }^{22}$ The more optimistic assumptions, assumptions I and II, assume (1) passenger employment will remain level at 45,000 and (2) non-passenger employment will decline at a constant annual rate of 0.5 percent for assumption I and 2.0 percent for assumption II for 25 years, at a reducing rate over the next 25 years, and remain level thereafter. A third and highly pessimistic assumption, widely viewed as highly unlikely, has passenger employment falling 500 workers per year for 20 years, then remain level at 35,000, and non-passenger employment declining 3.5 percent a year for 25 years, at a reducing rate over the next 25 years, and remain level thereafter. $25^{\text {th }}$ Actuarial Valuation, pp. 8.
} 
benefit ratio declining through 2025, to about 3 times annual outlays, then rising quite steadily thereafter (Figure 2.10a). The intermediate projection, Assumption II, based on a steeper employment decline, has the account benefit ratio declining through 2027, to about 2 times outlays, before rising thereafter at a milder pace (Figure 2.10b). A third projection, Assumption III, based on steep employment declines widely viewed as highly unlikely, shows a negative balance in 2036 and every year thereafter. The report nonetheless concludes "that, barring a sudden, unanticipated, large drop in railroad employment or substantial investment losses, the railroad retirement system will experience no cash flow problems during the next 23 years."23

Figure 2.9. Railroad Employment Projections, $25^{\text {th }}$ Actuarial Valuation

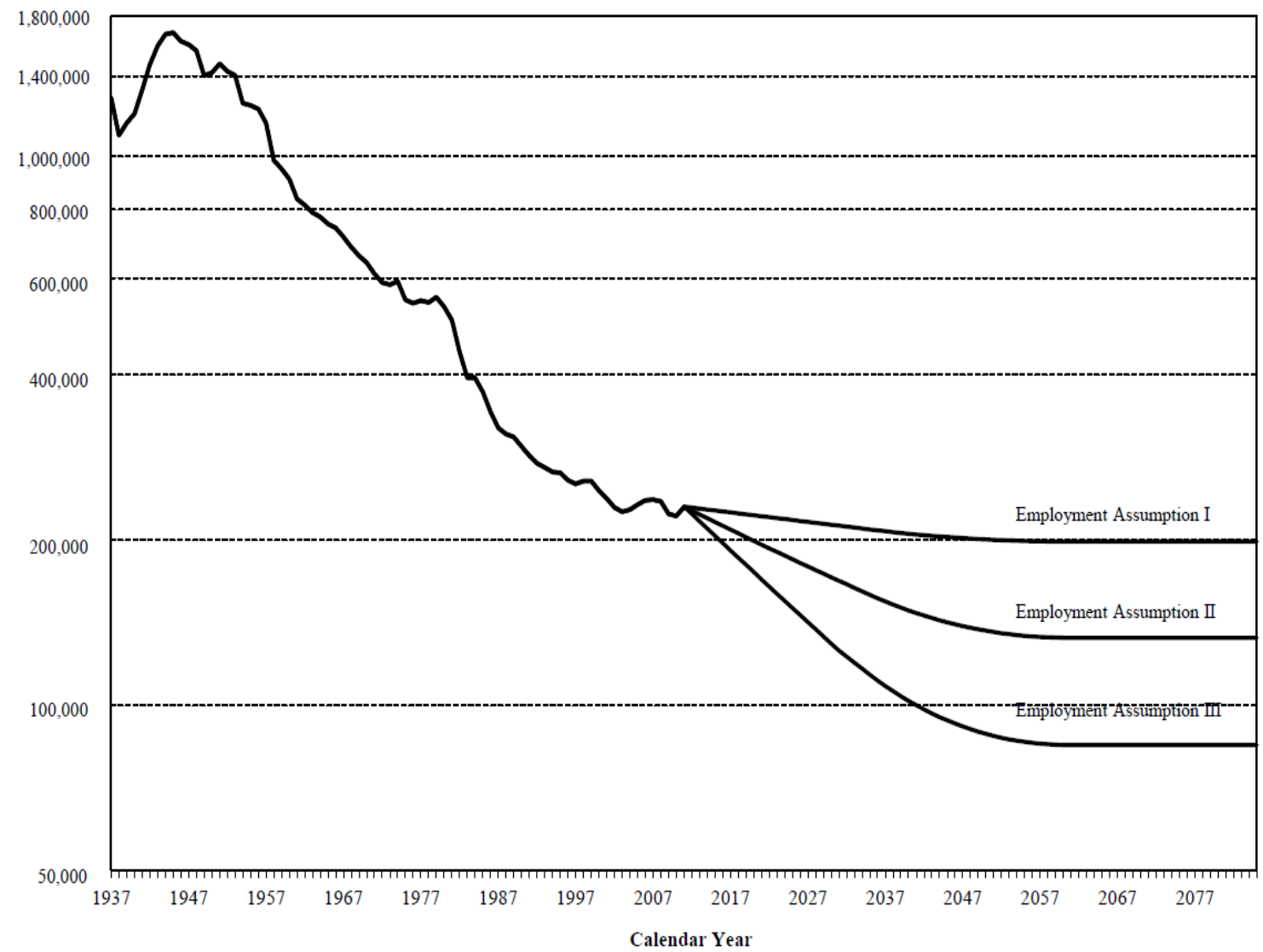

Source: U.S. Railroad Retirement Board (2012), Figure 1, pp. 15.

${ }^{23}$ U.S. Railroad Retirement Board (2012), pp. 2. 
Figure 2.10. Projected Gap Between Railroad Retirement Outlays and Tax Receipts

A. Employment Assumption I

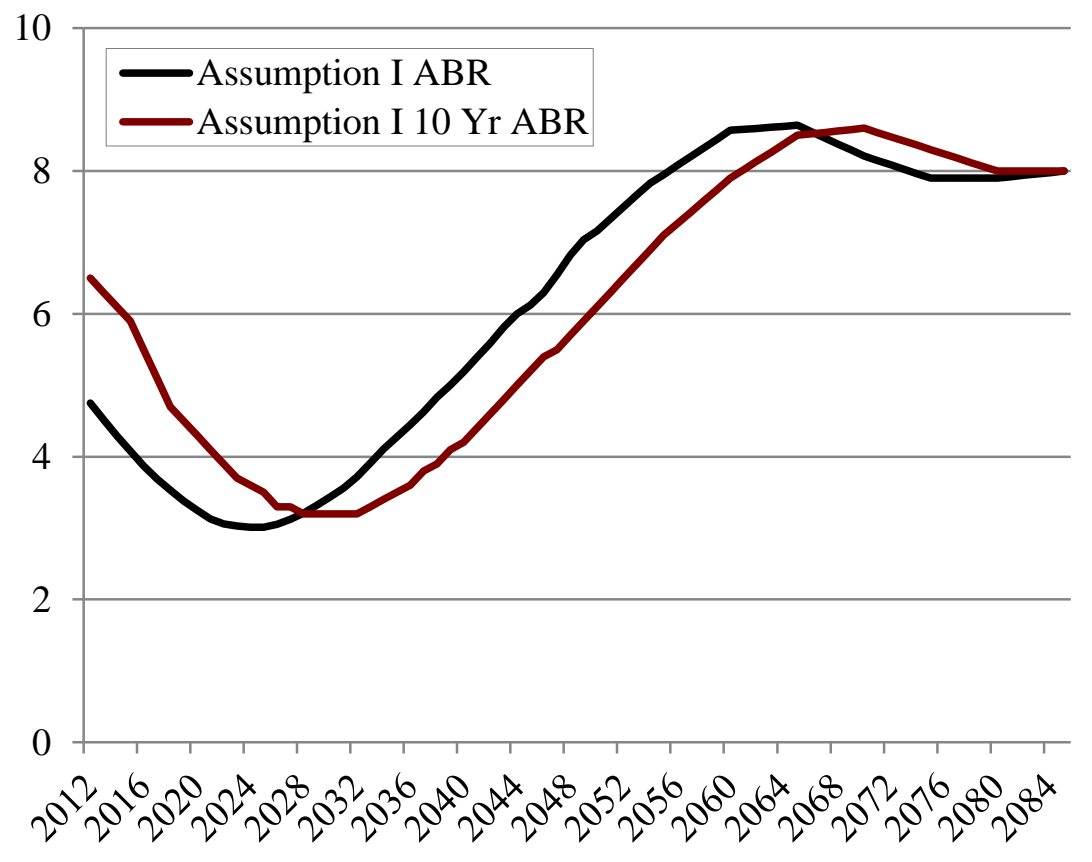

B. Employment Assumption II

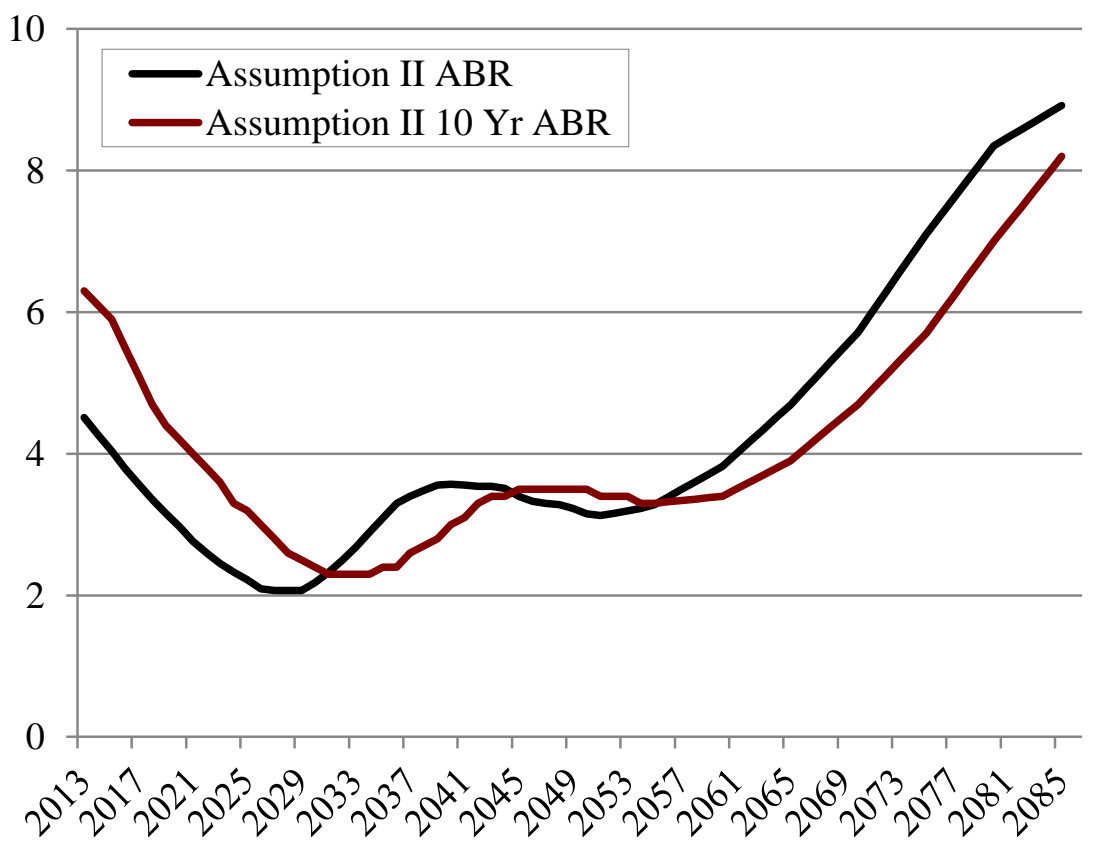




\section{Employment Assumption III}

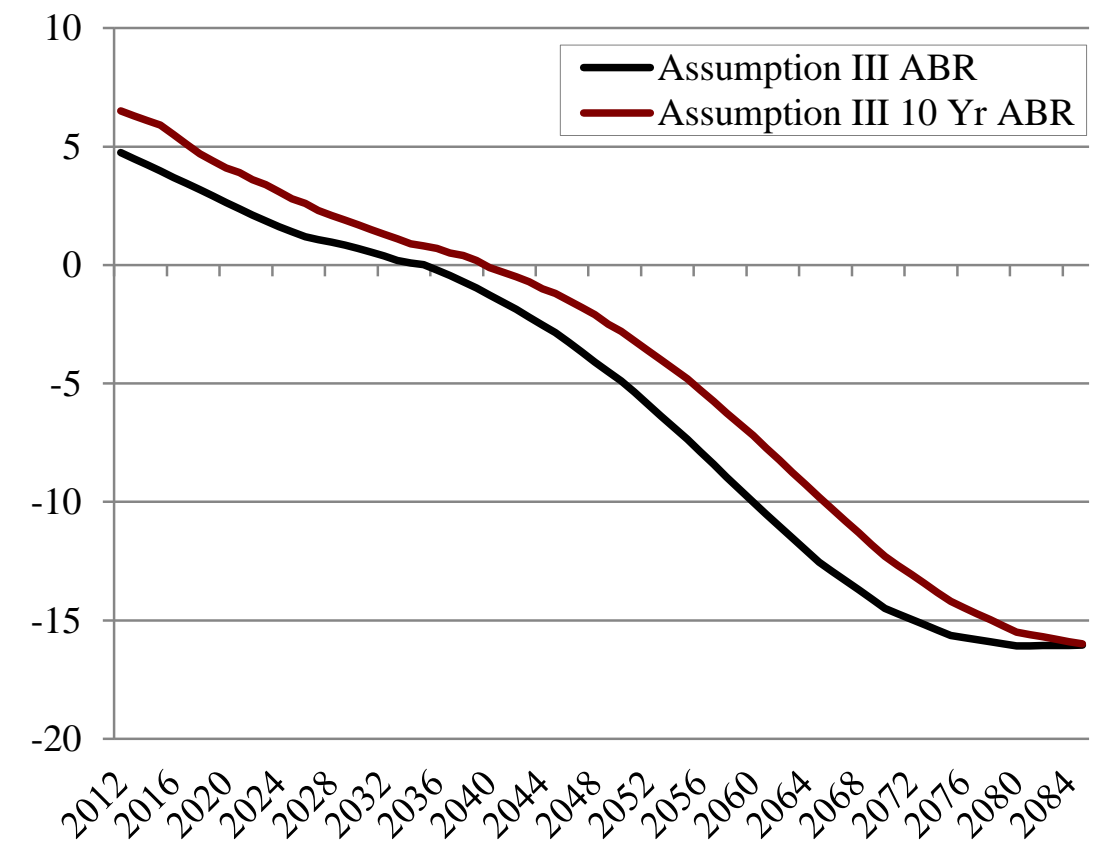

Source: U.S. Railroad Retirement Board (2012), Figure 1, pp. 15.

The triennial Actuarial Valuations of the Railroad Retirement program project the system's finances based on these three employment trajectories. The health of a pay-as-you-go retirement program is critically dependent on employment levels and the trajectory of rail employment has historically been hard to predict. This is the only risk factor addressed in the published Actuarial Valuations address. The program's dependence on cash transfers from the NRRIT, and the investment of NRRIT assets in equities, adds a significant new risk factor to the program's financial health. Valuations using lower long-run returns on NRRIT assets confirm that the long-term health of the Railroad Retirement program primarily depends on the trajectory of railroad employment. NRRIT assets, and adjustments in the tax rate, were generally seen as sufficient to buffer short-term cyclic swings,

The agreement reached in negotiations between management and labor, which RSSIA enacted, made the carriers responsible for the downside risk, whatever the source. The statute capped the tax on workers at the 4.9 percent rate in place when the bill became law. But future funding shortfalls could push the tax on carriers up to 22.1 percent of covered payroll, much higher than their pre-reform 16.1 percent rate. This contingent claim on the carriers is thus an asset the 2001 reform added to the Railroad Retirement program. 
The initial carrier tax reduction RSSIA introduced, from 16.1 to 13.1 percent, strengthened the carriers. As Railroad Retirement had a contingent claim on the carriers, healthier carriers strengthened the program. The 2012 Valuation projections, based on the intermediate employment assumption, had the carriers' tax rising to the new maximum 22.1 percent rate by 2030 and only trend down after 2037. But the carriers had paid a lower tax than they had prior to reform through 2014, and a projected rate no higher through 2026. The savings up to 2014 helped produce stronger cash flows, earnings, and balance sheets, which enhanced the carriers' ability to invest in plant, equipment, and other improvements. It also helped enhance the carriers' ability to access external sources of capital and reduced the cost of that capital. The railroads during this period made significant investments that boosted their ability to generate earnings and cashflow. Should the projections based on the intermediate assumption play out, these investments made in the early years of reform would help the carriers pay the higher tax rates projected after $2026 .^{24}$

While the carriers should be in a stronger position to bear the downside risk, the tax adjustment ratchet, the mechanism designed to manage risk, is designed to produce a rather sluggish response to shocks. The market Crash of 2008, admittedly a highly unusual event, illustrates how quickly the program's finances could sour without any tax response. During the post-crash period, the program's finances benefited from unexpectedly strong railroad employment, which reduced the demands on transfers from the Trust. As economic downturns typically reduce both employment levels and asset values, it seems reasonable to expect employment shocks to amplify, not dampen, future financial shocks.

The most recent Actuarial Valuation projects assets under Employment Assumption II hovering at 2 times annual outlays over the last half of the 2020s and not rising above 4 times annual outlays until the early 2060s. Two times annual outlays had been considered a comfortable cushion for the much larger and more stable Social Security program, with assets invested in Treasuries and benefits fully covered by payroll tax receipts. It is not such a comfortable cushion in the far less stable Railroad Retirement program, with a Trust Fund invested in risky assets, while the watermelon is still in the snake.

\footnotetext{
${ }^{24}$ The carrier tax rate under the optimistic employment assumption never rises above the rate they paid before the reform; under the pessimistic assumption, the carrier tax rate rises quickly above the pre-reform rate, but not quickly enough, nor high enough, to prevent insolvency.
} 
The success of the 2001 reform, however, does not depend solely on the ability of the ratchet to keep the program on-track. It depends on Congress (and the industry) having enough time to respond to shocks that overwhelm the ratchet's automatic response. And that it would seem able to do. The 2001 reform was largely developed assuming railroad employment would follow the more optimistic path predicted in the Actuary's Assumption I. Assumption I has in fact remained the most accurate projection of industry employment. But should Trust Fund assets fall below 3 times annual outlays, as projected under Employment Assumption II in 2020, it seems reasonable to expect Congress (or the industry) to develop a contingency plans to shore up the system. And it seems reasonable to expect Congress to act before the account benefit ratio falls to 2 times annual outlays, as projected under Employment Assumption II in the latter half of the decade. Whether Congress responds is harder to predict. But the reformed program would seem to provide enough time to shore up the system if need be.

\section{CONCLUSION}

The Railroad Retirement and Survivor's Improvement Act of 2001 introduced four major reforms. It raised benefits, cut taxes, created the National Railroad Retirement Investment Trust, and created a tax adjustment mechanism to help keep the program's finances on-track. The primary concern of Congress in enacting the reform was the risk of political influence on investment decisions. A secondary concern was the financial performance of the redesigned program.

Railroad Retirement is a government program; its assets are government assets; and the record of government investment of pension fund assets is checkered at best. A leading observer identified a set of "'good practices,' which are not commonly observed in public fund management. These were:

(i) explicit funding targets and mechanisms to trigger action in the case of deviation from this objective; (ii) commercial investment policies flowing from these targets and explicitly aimed at maximizing risk-adjusted returns for members; (iii) professional boards selected through a process that maintains an 'arms-length' relationship with government officials; (iv) prohibition on social investment criteria or ETIs [economically targeted investments]; (v) significant share of investment done through external managers selected and retained by explicit and objective criteria; (vi) avoidance of strict portfolio 
limits, especially on foreign investments and (vii) high standards of reporting and disclosure including annual, independent audits, performance reviews, and codes of conduct for Board members available to the public." ${ }^{25}$

By these criteria, the NRRIT is an exemplary manager of public pension assets.

A recent review of the NRRIT governance structure likewise concluded that thus far "the NRRIT appears to have achieved the political independence Congress desired." ${ }^{26}$ That review cited five contributing factors: 1) the Trust's legal status as an independent non-government entity; 2) the ERISA-based "mandate" to invest Railroad Retirement assets prudently and solely in the interest of the plan and plan participants; 3 ) the "professional" character of NRRIT Trustees, who represent both management and labor; 4) the professional development of investment guidelines and benchmarks, primarily carried out by external investment managers; and 5) an effective system of financial reporting and oversight.

The basic explanation of this success is that all parties - the Congress, the carriers, and the unions - wanted the NRRIT to function like a modern private pension trust. The governance of such trusts has been well-developed under ERISA mandates, and decades of experience, to act as Congress intended - solely to advance the interests of the plan and its participants, using transparent and sophisticated investment management practices.

Of more concern is the financial design of the reformed Railroad Retirement program. The reformers had far less precedent upon which to build the new design and selected key parameters in a somewhat ad hoc manner. The 4 times annual benefits threshold, below which the ratchet would increase payroll taxes, was set because 4 times annual benefits was the ratio assets to outlays at the time, and historically high in the Railroad Retirement program. The decision to use a 10 year average of that ratio as the basis for setting the tax rate was chosen to dampen shocks on carrier cash flows and reduce the volatility on employee tax rates. The performance of the financial markets in the first decade of reform - admittedly a historically volatile period - illustrates the limits of the ratchet's ability to stabilize the program's finances. The experience over the next decade and a half, as the watermelon squeezes through the snake, will largely determine whether or not the program's finances might need shoring up.

\footnotetext{
${ }^{25}$ Palacios (2002) p.40.

${ }^{26}$ Whitman (2011) p.81.
} 
The longer-term future of Railroad Retirement is harder to predict. As illustrated by the projections in the latest Actuarial Valuation, much depends on the course of future railroad employment. If the program emerges from the 2020s in a very healthy condition, labor could seek sweetened benefits, management could seek lower taxes, or the government, and perhaps management, could again seek privatization. If the program emerges in a weakened condition, benefits could fall, taxes rise, and the government could be forced to help shore up the system. Over the history of the program, however, the government has placed the primary burden of shoring up the Railroad Retirement system on rail management and labor. The 2001 Act, in effect recognizing that reality, gave management and labor responsibility for investing the program's assets. If the system needs shoring up at some point in the future, that is where the primary burden will fall.

The history of railroad pensions illustrates the long-term nature of such programs and their dependence on decisions made in the past. Employer pension programs hold claims created during an employee's working years for income many decades in the future - in the employee's retirement years and the retirement years of their surviving spouses. How those claims are realized, or transmuted, is rarely in the same institutional setup in which they were granted. In all likelihood, the 2001 reforms will not be the last restructuring of the Railroad Retirement program. 


\section{References}

Brown, Jeffrey R., Joshua Pollet, and Scott J. Weisbenner. 2009. "The Investment Behavior of State Pension Plans." Cambridge, MA: National Bureau of Economic Research.

Congressional Record. 2001. Railroad Retirement and Survivors' Improvement Act of 2001. Public Law 107-90. Congressional Record 147. Authenticated U.S. Government Information.

Ibbotson Associates. 2013. SBBI Classic Yearbook 2013: Market Results for Stocks, Bonds, Bills, and Inflation 1926-2010. Chicago, IL: Morningstar, Inc.

Mercer. 2011. Responsible Investment's Next Decade: Developing CalPERS Total Fund Process for ESG Integration: Discussion Document Prepared for CalPERS ESG Board Workshop, August 15, 2011. New York: Mercer LLC.

Munnell, Alicia H. and Annika Sundén. 1983. "The Pitfalls of Social Investing: The Case of Public Pensions and Housing." New England Economic Review (September/October): 2040.

Munnell, Alicia H. and Steven A. Sass. 2006. Social Security and the Stock Market: How the Pursuit of Market Magic Shapes the System. Kalimazoo, MI: W.E. Upjohn Institute for Employment Research.

National Railroad Retirement Investment Trust. 2002-2012. Annual Management Reports. Chicago, IL: U.S. Railroad Retirement Board.

Palacios, Robert. 2002. Managing Public Pension Reserves: Part II: Lessons from Five Recent OECD Initiatives. Washington, DC: The World Bank.

Salmon, John. 2013. "The Creation of the National Railroad Retirement Investment Trust: Improving Railroad Retirement for Labor, Management and Beneficiaries: 1995-2002.” Manufacturers Standardization Society.

Sass, Steven A. 1992. "Public Pension DOs and DON'Ts," Regional Review Spring: 21-24. Federal Reserve Bank of Boston.

1997. The Promise of Private Pensions. Cambridge, MA: Harvard University Press.

Szymendera, Scott. 2011. "Railroad Retirement Board: Trust Fund Investment Practices." CRS Report for Congress Order RS22782. Congressional Research Service: Washington, DC.

U.S. House of Representatives, House Committee on Appropriations. 2007. Departments of Labor, Health and Human Services, and Education, and Related Agencies Appropriations Bill, 2008. Report 110-231. Washington, DC: Government Printing Office. Available at: http://www.gpo.gov/fdsys/pkg/CRPT-110hrpt231/pdf/CRPT-110hrpt231.pdf. 
U.S. Railroad Retirement Board. 2000. "21st Actuarial Valuation of the Railroad of the Assets and Liabilities Under the Railroad Retirement Acts as of December 31, 1998 with Technical Supplement." Chicago, IL.

U.S. Railroad Retirement Board. 2003. " $22^{\text {nd }}$ Actuarial Valuation of the Railroad of the Assets and Liabilities Under the Railroad Retirement Acts as of December 31, 2001 with Technical Supplement." Chicago, IL.

U.S. Railroad Retirement Board. 2012. " $25^{\text {th }}$ Actuarial Valuation of the Railroad of the Assets and Liabilities Under the Railroad Retirement Acts as of December 31, 2010." Chicago, IL.

Whitman, Kevin. 2011. "Managing Independence: The Governance Components of the National Railroad Retirement Investment Trust.” Social Security Bulletin 71(2): 77-84. 


\section{RECENT WORKING PAPERS FROM THE \\ CENTER FOR RETIREMENT RESEARCH AT BOSTON COLLEGE}

\section{Reforming the Railroad Retirement System}

Steven A. Sass, June 2013

How Do the Disabled Cope While Waiting for SSDI?

Norma B. Coe, Stephan Lindner, Kendrew Wong, and April Yanyuan Wu, June 2013

The Impact of Population Aging and Delayed Retirement on Workforce Productivity Gary Burtless, May 2013

Does Access to Health Insurance Influence Work Effort Among Disability Cash Benefit Recipients?

Norma B. Coe and Kalman Rupp, April 2013

How Will Older Workers Who Lose Their Jobs During the Great Recession Fare in the Long-Run?

Matthew S. Rutledge, Natalia Orlova, and Anthony Webb, March 2013

Can Long-Term Care Insurance Partnership Programs Increase Coverage and Reduce Medicaid Costs?

Wei Sun and Anthony Webb, March 2013

SSI for Disabled Immigrants: Why Do Ethnic Networks Matter?

Delia Furtado and Nikolaos Theodoropoulos, February 2013

The Use of VA Disability Benefits and Social Security Disability Insurance Among Veterans

Janet M. Wilmoth, Andrew S. London, and Colleen M. Heflin, February 2013

How Does the Composition of Disability Insurance Applicants Change Across Business Cycles?

Norma B. Coe and Matthew S. Rutledge, February 2013

The Economic Implications of the Department of Labor's 2010 Proposals for BrokerDealers

Alicia H. Munnell, Anthony Webb, and Francis M. Vitagliano, January 2013

What Is the Long-Term Impact of Zebley on Adult and Child Outcomes?

Norma B. Coe and Matthew S. Rutledge, January 2013

All working papers are available on the Center for Retirement Research website (http://crr.bc.edu) and can be requested by e-mail (crr@bc.edu) or phone (617-552-1762). 